Similarly, thyroglobulin $(0 \cdot 8-4 \cdot 0 \mathrm{mgm}$. per ml.) and iodinated casein $(2.0 \mathrm{mgm}$. per ml.) were devoid of significant in vitro influence on the activity of these enzymes.

The enhanced muscle hexokinase activity of the thyroxine-treated animals can, perhaps, be correlated with the increased rate of carbohydrate metabolism in experimental hyperthyroidism. The lack of influence of thyroxine administration on liver-choline oxidase emphasizes that the thyroid hormone does not affect all the respiratory enzymes of rat liver. Furthermore, it seems that although the activity of both muscle hexokinase and liver succinoxidase of thyroxine-treated rats is significantly enhanced, similar changes cannot be simulated by the in vitro addition of either thyroxine or the thyroxinecontaining proteins thyroglobulin and iodinated casein to preparations of these enzymes isolated from normal animals.

\section{R. H. Smith}

H. G. WILliams-AshmaN

Department of Biochemistry,

University College,

Gower Street,

London, W.C.1. March 23.

' Klein, J. R., J. Biol. Chem., 128, 659 (1939).

Tipton, S. R., Leath, M. J., Tipton, I. H., and Nixon, W. L., Amer. J. Physiol., 145, 693 (1945).

${ }^{3}$ Hawkins, R. D., Nishikawara, M., and Mendel, B., Endocrinol., 43, 167 (1948).

${ }^{4}$ Kochakian, C. D., and Bartlett, M. N., J. Biol. Chem., 176, 243 (1948).

${ }^{5}$ Colowick, S. P., Cori, G. F., and Slein, M. W., J. Biol. Chem., 168, 395 (1947).

- Nelson, N., J. Biol. Chem., 153, 375 (1944).

${ }^{1}$ Tipton, S. R., and Nixon, W. L., Endocrinol., 39, 300 (1946).

\section{Availability of the Magnesium of Grass to the Ruminant}

HITHERTo, it has, apparently, been assumed that the magnesium of chlorophyll is split ofi under the action of the gastric juice and thus becomes available for absorption. I have been able to find no experimental evidence to verify this assumption.

Sterile grass powder was incubated with a suspension of ruminal organisms, obtained from the sheep or ox, under conditions reproducing, so far as possible, those in the rumen. After 'ruminal' digestion, which was allowed to proceed for $36-72 \mathrm{hr}$., the reaction mixture was brought to $p H 2$ by addition of $0.02 \mathrm{~N}$ hydrochloric acid to simulate conditions in the abomasum, and incubated for a further three to twenty-four hours. The ultrafilterable magnesium present at the end of the 'ruminal' and 'abomasal' phases was estimated.

The results obtained are summarized in the accompanying table :

\begin{tabular}{|c|c|c|c|}
\hline \multirow{2}{*}{$\begin{array}{l}p \mathrm{H} \text { of 'rum- } \\
\text { inal' contents }\end{array}$} & \multirow{2}{*}{$\begin{array}{c}\text { Number of } \\
\text { experiments }\end{array}$} & \multicolumn{2}{|c|}{$\begin{array}{l}\text { Ultraflterable magnesium } \\
\text { (as per cent total magnesium } \\
\text { present) }\end{array}$} \\
\hline & & $\begin{array}{c}\text { Ruminal organ- } \\
\text { isms present }\end{array}$ & $\begin{array}{l}\text { Ruminal organ- } \\
\text { isms absent }\end{array}$ \\
\hline $\begin{array}{c}\text { After 'ruminal } \\
6.9 \\
7 \cdot 8 \\
8.9 \\
\text { After 'abomas } \\
6 \cdot 9 \\
7 \cdot 8 \\
8.9\end{array}$ & \begin{tabular}{|c} 
digestion : \\
4 \\
1 \\
4 \\
1 ' digestion \\
5 \\
1 \\
4
\end{tabular} & $\begin{array}{c}85 \cdot 0 \pm 0 \cdot 9 \\
\text { Nil } \\
\text { Nil } \\
96 \cdot 0 \pm 1 \cdot 2 \\
100 \cdot 5 \pm 1 \cdot 6 \\
93 \cdot 5 \pm 1 \cdot 5\end{array}$ & $\begin{array}{l}80 \cdot 0 \pm \\
\text { Nil } \\
\text { Nil }\end{array}$ \\
\hline
\end{tabular}

By applying the $t$ test to the results obtained with and without ruminal organisms at all values of 'ruminal' $p H$, it is found that $P$ lies between 0.05 and $0 \cdot 02$. Assuming that the ' $0 \cdot 05$-level of significance' is satisfactory as a criterion, it is evident that rum. inal organisms play a significant part in the liberation of magnesium from plant cells.

The absence of free magnesium in the alkaline 'rumen' is probably due to the formation of insoluble salts, from which it is liberated by the action of the abomasal hydrochloric acid.

I have to thank the Director of Veterinary Services, Nigeria, for permission to publish this note.

Research Department, R. J. Garner

Veterinary Department, Vom, Bukuru P.O., N. Nigeria. March 3.

\section{Persistence of Pyrethrins and Gamma Isomer of Benzene Hexachloride}

IT is well known that both light and air rapidly destroy the pyrethrins, therefore to obtain a true picture of the relative persistence of pyrethrins and the gamma isomer of benzene hexachloride as a protector of grain, the scales should not be weighted against the pyrethrins by exposing the treated grain in open jars, as is done in Bovingdon's experiment'. Furthermore, the quantities of pyrethrins used in his experiment are very much less than those in mine ${ }^{2}$. Bovingdon's applications, in the terms of pyrethrum powder, containing $1 \cdot 3$ per cent pyrethrins, work out at $1 \frac{1}{4}, 2 \frac{1}{2}, 5$ and $6 \frac{1}{2} \mathrm{oz}$. of the powder to a $200-\mathrm{lb}$. bag of grain.

The persistence of the toxic effect of the pyrethrum powder in my experiments was most unexpected; but possibly this is due to the fact that the pyrethrum powder was in the dark, and the oxygen content of the atmosphere within the bags, owing to respiration of the grain, was lower than the normal atmosphere.

Although gamma hexachloride, at a concentration of 0.5 p.p.m., will kill Sitophilus granarius and Sitophilus oryzce, even at double this concentration, it is non-effective against Tribolium castaneum. It is also not yet definitely known whether even at this low concentration there may not be definite toxic effects to mammals regularly taking grain treated with benzene hexachloride. Lehman reports that it is impossible to feed, in a single dose, a sufficient quantity of the beta isomer of benzene hexachloride to kill a rat, yet when fed over a long period, a concentration as low as 10 p.p.m. produced gross evidence of poisoning ${ }^{3}$. There has been no evidence of poisoning by pyrethrum or the pyrethrins.

Pyrethrum Board of Kenya,

\section{A. BECKLEY}

\section{P.O. Box 338 \\ Nairobi. \\ May 31.}

${ }^{1}$ Bovingdon, H. H. S., Nature, 163, 731 (1949).

2 Beckley, V. A., Nature, 162, 737 (1948).

${ }^{3}$ Insecticidal Residues Subject: Agric. Chemicals IV, 33 (Feb. 1949).

IN reply to the queries raised by Mr. Beckley, I should like to record that the experiments described in my original letter were carried out merely to com. pare the toxicity and persistence of pyrethrins and 